\title{
The Dismal Science of Post-Marxist Political Theory: Is There a Future in Postindustrial Socialism?
}

\begin{abstract}
The fusion of postindustrial social theory with a new left political critique of classical Marxism resulted in a distinctly Post-Marxist political theory. This distinct political theory emerged during the 1980s, although it was quickly pushed aside by globalization studies in the 1990s. This paper argues that Post-Marxism is conceptually distinct from post-modernism, post-structuralism, and other variants of the New Left with most fundamental distinction being the idea that Marxian concepts are still necessary, if not sufficient for understanding postindustrial and global capitalism. More specifically, theorists such as André Gorz, Jürgen Habermas, Antonio Negri, and Claus Offe, among others, have articulated the foundations of this uniquely Post-Marxist political theory by anchoring their economic analysis of postindustrial capitalism in Marx's Grundrisse rather than Capital. This conceptual shift has enabled Post-Marxists to construct a theoretically powerful analysis of postindustrial capitalism, the new movements, and socialist policy that was remarkably prescient, although none of the Post-Marxists has successfully solved the problem of a contemporary historical subject and political agency.
\end{abstract}

Keywords: Post-Marxism, Post-Industrial Socialism, Guaranteed Annual Income, Marxist political economy, Surplus population, André Gorz, Jürgen Habermas, Antonio Negri, Claus Offe

The working population therefore produces both the accumulation of capital and the means by which it is itself made relatively superfluous; and it does this to an extent which is always increasing. 
Marxism's political and intellectual attractiveness began to wane in the late 1970s with the decline of traditional labor movements, the crisis of the welfare state, and the increasingly dismal electoral fortunes of social-democratic and left-wing parties (Pierson, 1995). As these traditional vehicles of left-wing and progressive politics seemed to disintegrate, a variety of "new social movements" emerged to articulate the political demands of ethnic and national minorities, welfare recipients, the elderly, unemployed youth, pacifists, women, the environment, and alternative life-styles (Boggs, 1986; Kriesi, 1995). The apparent rise of political groups formerly perceived as marginal to the dynamics of capitalist society seemed to require a "new left" political theory with the capacity to either go beyond traditional Marxism conceptually or to replace Marxist political theory altogether (Laclau, Mouffe, 1985; Touraine, 1987). The development of a distinct and identifiable Post-Marxist political theory was one of the numerous responses to this crisis of historical materialism (Anderson, 1976; Aronowitz, 1981; Giddens, 1983; Aronson, 1995).

Significantly, the emergence of Post-Marxist political theory occurred in conjuncture with the rise of postindustrial social theories, which the new left first began to take seriously with the publication of Alain Touraine's The Post-Industrial Society (1971) and Daniel Bell's The Coming of Post-Industrial Society (1973) (see: Frankel, 1987). These two theoretical innovations merged intellectually in the writings of radical social theorists such as André Gorz, Jürgen Habermas, Antonio Negri, and Claus Offe, who began to explore the theoretical implications of post-industrialism through the lens of classical Marxist theory. This fusion of the new left political critique of classical Marxism with postindustrial social theory resulted in a distinctly post-Marxist political theory that is conceptually distinct from post-modernism, post-structuralism, and the numerous identity movements associated with the new left. The purpose of this paper is to outline the basic contours of Post-Marxist political theory and to identify the generally dystopian and dismal social and political trajectories implied by this theory.

\section{The Intellectual Origins of Post-Marxism}

Many scholars will be familiar with the individual writings of prominent scholars, such as Gorz, Habermas, Negri, and Offe, but by the turn of the millennium some scholars were beginning to recognize their collective work as a "well-established theoretical position" called Post-Marxism. However, as Sim notes, the term post-Marxism first appears in Hegemony and Socialist Strategy (1985, p. 5) by Ernesto Laclau and Chantal Mouffe, who injected ambigui- 
ty into the term from the outset by distinguishing between post-Marxist and post-Marxist political theory. ${ }^{1}$ Sim's $(2001$, p. 1$)$ intellectual history of Post-Marxism is self-consciously and primarily focused on what Laclau and Mouffe call post-Marxism, which is equated with the explicit rejection of Marxism, rather than going beyond Marxism. Following the lead of Laclau and Mouffe, Sim identifies post-Marxism with deconstructionism and post-structuralism (Derrida, Laclau and Mouffe), post-modernism (Lyotard, Foucault, Baudrillard, Deleuze and Guattari), and second wave feminists (Hartmann, Butler, Haraway). Thus, Sim's intellectual history of Post-Marxism has only five references to Habermas, four references to Gorz, one reference to Antonio Negri, and no references to Claus Offe, although Habermas and Gorz do receive an extended treatment as key figures in the emergence of post-Marxism. In contrast to Sim's work, this paper is focused self-consciously and primarily on an analysis of post-Marxism as defined by Laclau and Mouffe, Sim, and in my earlier book, Critical Theories of the State (1993, Chap. 4), which all identify Gorz, Habermas, Negri, and Offe as central figures in the emergence of post-Marxism.

Sim argues (2001, p. 5) that the effort to grapple with "the decline in importance, both socially and politically, of the working class" is the key theoretical problem shared by both post-Marxism and post-Marxism and this problem, of course, is a consequence of the shift from an industrial to a post-industrial society. However, Sim also correctly argues that a key point of commonality among post-Marxists, and what distinguishes them from post-Marxists is that Marxism remains "at the very least, the point of departure for their theoretical speculations." However, Sim (1998, p. 7) incorrectly dismisses the post-Marxists' retention of Marxian analytic categories "as a series of somewhat empty gestures, whose content is emotional rather than theoretical." Sim (1998, pp. 8-9) considers the post-Marxists' effort to retain a theoretical anchor in Marx as nothing more than "nostalgia" and a "romantic gesture," but what Sim misses in his analysis is the central role of Grundrisse (as opposed to Capital) in anchoring a genuinely post-Marxist position that continues to anchor its analysis of society, politics, and the state in Marxian political economy.

The discovery of Grundrisse by Western Marxists generated a shift in thinking about Marx and Marxism as dramatic as the one that occurred after the

Sim (1998, pp. 1-2) observes that "the work of Ernesto Laclau and Chantal Mouffe has played a critical role in the development of post-Marxism, particularly their book Hegemony and Socialist Strategy: Towards a Radical Democratic Politics (1985), which helped to establish postMarxism as a definite theoretical position in its own right." More recently, Harrison (2014, p. 3) has also observed that "the work of the late Ernesto Laclau is still considered by many as synonymous with post-Marxism," but "they used the term in at least two senses." 
discovery and publication of Marx's early writings, such as the Economic and Philosophical Manuscripts of 1844 and The German Ideology. While the early manuscripts provided the theoretical basis for a new humanist Marxism as compared to the scientific Marx, Grundrisse became the cornerstone for a newly emergent Post-Marxism grappling with the social dislocations of post-industrial technologies as compared to industrial machinery. The discovery of Grundrisse was first announced to the Socialist Academy (Moscow) in 1923, but it was not published until 1939 and 1941 when it was released in two volumes. However, in the midst of World War II and then the Cold War, Grundrisse was effectively inaccessible to Western scholars until 1953 when it was published in German as a single volume by Dietz Verlag.

Nevertheless, Grundrisse was largely ignored after its publication in Germany, because scholars viewed the previously unpublished manuscript as nothing more than a "rough draft of Capital" (McLellan, 1971, p. 2, fn. 4) that at best provided "interesting material for a reconstruction of the genesis of Capital" (Nicolaus, 1968, p. 43). It was another decade before Herbert Marcuse (1964, pp. 35-36) and André Gorz (1967, pp. 128-130) became the first scholars to quote Grundrisse extensively in their New Left critiques of advanced capitalism. Yet, Grundrisse's significance was still not widely recognized until Martin Nicolaus (1968, p. 42) devoted an entire article to it in the New Left Review and identified it as the only writing that Marx himself considered to be a representation of "the whole of his views." Thus, the intellectual stage had been set for New Left political theorists and political economists to reassess the status of Grundrisse, which was now recognized as a work that envisioned a grand treatise on political economy with Capital (in all its volumes) being only one small component of a more expansive and forward looking Marxism (McLellan, 1971, p. 9). David McLellan (1971, pp. 2-3) subsequently translated and edited an abridged English language version of Grundrisse, while introducing the book as "the most fundamental of all Marx's writings" and as "the centerpiece of Marx's thought." Shortly thereafter, in 1973, McLellan's preliminary effort was superseded by a complete English language edition translated by Martin Nicolaus, which further stimulated interest in the book, particularly with the onset of the global stagflation crisis of the 1970s and the first glimpses of globalization as a response to that crisis.

By 1979, Julius Sensat (1979, pp. 68-72) concludes that Habermas had shifted his focus from Capital to Grundrisse and this change of perspective defined a fundamental break with classical Marxian political economy based on the labor theory of value. Indeed, Sensat (1979) offers a lengthy analysis of what he calls a "controversial text" (pp. 117-122) and frequently refers to it (pp. 99, $105-106,109)$ as the foundation of Habermas' revised conception of historical 
materialism. ${ }^{2}$ Similarly, Adrian Little (1996, p. 164) concludes that Gorz's "work is firmly grounded in the Marxian tradition, a point emphasized by the constant recourse to Grundrisse" in his works, while Conrad Lodziak and Jeremy Tatman (1997, p. 100) similarly suggest that the life-long trajectory of Gorz's thinking was the systematic development of his earliest observations about the possibility of "an alternative thesis in Marx" anchored in Grundrisse, rather than Capital. Little (1996, p. 173) finds that Gorz's work "is littered with references to Marx's Grundrisse" and it is these references that "locate Gorz's position within the Marxian tradition." More broadly, Kathi Weeks (2005, p. 118) suggests that "Whereas Capital is the principal text of classical Marxism and the Manuscripts the key text for the humanists [...] in Marx Beyond Marx, a study of the Grundrisse, Negri finds the outlines of an alternative to many existing Marxisms, including both the classical and the humanist traditions."3

Consequently, I argue that the most fundamental distinction between PostMarxism (post-Marxism) and other post-ideologies/theories is the idea that Marxian concepts are still necessary, if not sufficient for understanding postindustrial and global capitalism. More specifically, Gorz, Habermas, Negri, and Offe, among others, articulate the foundations of a uniquely Post-Marxist political theory by anchoring their economic analysis of capitalism in Marx's Grundrisse rather than Capital (see also: Harvey, 1982; Negri, 1991). This conceptual shift made it possible to construct a theoretically powerful analysis of postindustrial capitalism, the new social movements, and socialist strategy, while drawing on the most basic insight of classical Marxism that the economic is determinative in the last instance. While Marx's Capital remains an important text for the Post-Marxian theorists, it is Grundrisse that rises to the forefront of their economic analysis and provides the conceptual foundation for a postindustrial,

Reichelt (2000, p. 116) argues correctly in my view that "Habermas' theoretical work did not develop in a straight line [...] one has to differentiate between Habermas I and Habermas II." Reichelt suggests that this "break in the elaboration of his theory [...] this new beginning originated with his turn to linguistic theory [...] discourse theory and linguistic pragmatism" (i.e., The Theory of Communicative Action). Another way of drawing this distinction is to say that Habermas I was a political sociologist, while Habermas II is a language philosopher and a theorist of some future deliberative democracy. In this respect, I am concerned exclusively with the work of Habermas I, which is a critique of contemporary capitalism and the state, although most of the secondary scholarly literature on Habermas focuses on Habermas II. Baynes (2016, p. 2), echoes Reichelt's assessment by noting that early in Habermas' career "Marx (and the wider Hegelian-Marxist tradition of critical theory) engaged his thought," while the period from The Theory of Communicative Action onward "might be described as more Weberian and in which his conception of social theory looks more 'traditional' than 'critical.'

See: Callinicos (2005, pp. 170-181) for an insightful analysis of the role of Grundrisse in Negri's political economy and theory of the state. 
as opposed to a post-modern, post-structuralist, or post-capitalist, reading of Capital and other of Marx's political writings. ${ }^{4}$

\section{The Labor Market: A Power-Generating System}

In the works of leading Post-Marxist theorists such as Claus Offe, Jürgen Habermas, Antonio Negri, and André Gorz, capitalism is conceptualized as a system (Barrow 1993, Chap. 4). The capitalist system is actually a matrix of three interdependent but relatively autonomous subsystems: the economic system, the political system, and the socialization system. The most important institutions associated with the economic subsystem are the relations of production between classes in the workplace and relations of exchange between buyers and sellers in the marketplace. The socialization subsystem, from which individuals derive normative values, includes the family, educational institutions, religion, and culture. The political subsystem consists primarily of those institutions and policies that define the state.

Importantly, though each subsystem encompasses concretely identifiable institutions, the system as a whole is posited as an ontological entity - real in itself - which produces consequences through institutions, but which is therefore never reducible to institutions. Offe (1984, p. 37) maintains, for example, that the capitalist system is a "superordinate level of mechanisms that generate 'events'." However, the superordinate reality of this system is only observable empirically when those mechanisms that fulfill a maintenance function fail to suppress the underlying contradictions of the capitalist mode of production. A contradiction, according to Offe (1984, p. 132), "is the tendency inherent within a specific mode of production to destroy those very pre-conditions on which its survival depends." Consequently, the historical development of a contradiction must inevitably culminate in some crisis event that makes the contradiction perceptible as a crisis (Offe, 1984, p. 116, fn. 15).

In contrast to post-modernists who deride Marx's "productivism," PostMarxian theorists continue to identify the relative dominance of the economic subsystem in capitalist society as the basis of contradictory dynamics within the overall capitalist system. ${ }^{5}$ Claus Offe locates the pivotal contradiction of capital-

Gorz (1989, p. 1) echoes a theme often articulated by Habermas: "What we are experiencing is not the crisis of modernity. We are experiencing the need to modernize the presuppositions upon which modernity is based [...] an indication of the need for modernity itself to be modernized." See also: Offe (1996, pp. 3-5).

5 For example, Habermas (1970, p. 90) states that his objective is "to construct a conceptual model of institutional change brought about by the extension of subsystems of purposive-rational action" (i.e., the economic system) to the normative spheres of the life-world (i.e., politics and culture). 
ism in the structure of labor markets where the legal exchange of commodities between equals (labor-power for wages) must coexist with an unequal distribution of property (social relations of production). Offe (1985a, p. 53) emphasizes that capitalist labor markets can exist only to the extent that workers are propertyless in two senses: "Labor can neither be the property of another nor possess property."

In the first instance, labor markets are only possible to the extent that labor is free and mobile and, thus, available for sale on the market in exchange for wages. Yet, as Offe (1984, pp. 92-93) also observes, the emergence of a market in laborpower is not necessarily the "natural" outcome of liberating labor from pre-capitalist forms of bondage such as serfdom or slavery. A second and more coercive condition for the existence of labor markets is that workers cannot control property, and thus cannot control their own chances of securing an existence outside of the labor market. Wages offer the inducement, but propertylessness imposes the necessity of an individual's entry into the labor market.

Hence, the asymmetrical structure of the capitalist labor market establishes an unequal bargaining position between laborers and capitalists. Quite simply, capitalists are always in a position to out-wait workers and to strike a more favorable bargain in the negotiation of wage contracts because they own the means of production. In this respect, labor markets constitute "the most significant feature of capitalist social structures" because they are a "power-generating mode of interaction that leads to a relatively stable and consistent matrix of social power" within capitalist societies (Offe, 1985a, p. 2). ${ }^{6}$ However, Offe contends that an economic subsystem organized by the labor market is continually threatened by potential disintegration to the extent that labor-power is not really a commodity (cf. Polanyi, 1957).

Labor-power is a "fictive commodity" in the sense that one cannot physically separate it from the laborer nor, therefore, unequivocally transfer rights to it in the process of exchange. Labor-power and the laborer are in fact inseparable. As a result, any extended reproduction of the economic subsystem requires the uninterrupted support of a socialization subsystem and the persistent intervention of the political subsystem. A labor market can operate smoothly only to the extent that socialization mechanisms sustain a normative structure in which it is legitimate to view labor-power as if it was a commodity. Yet, the labor market itself does not provide such mechanisms but instead generates class conflict.

Therefore, the political system must increasingly support the socialization subsystem and supply both the coercion and the inducements necessary to maintain the asymmetry of labor market exchanges (Bowles, Gintis, 1982). Offe

Offe's (1985a, p. 1) methodological premise is that power "is an attribute not of actors, but of modes of interaction.” For a more extensive discussion see: Offe (1985a, pp. 10-51). 
(1984, p. 98) refers to these interventions as social policy. The operational objective of social policy is to establish "a state strategy for incorporating labor power into the wage labor relation." ${ }^{7}$ By contributing to the constitution of the working class, particular configurations of social policy (i.e., state forms) make the appropriation of surplus value possible at each stage of capitalist development (Borchert, Lessenich, 2016).

\section{The Logic of Capital: Beyond the Law of Value}

Post-Marxists argue that Marx was wrong historically in assessing the long-term implications of technological development for working class formation, precisely because he was theoretically correct in understanding the logic of capitalism. For instance, André Gorz (1986, p. 8) begins his analysis of postindustrial capitalism by acknowledging that orthodox Marxist economists such as Ernest Mandel, Paul M. Sweezy, and others had correctly predicted "the exhaustion of economic growth and the advent of a depressive cycle" in late capitalism using traditional Marxian categories. ${ }^{8}$ Most importantly, orthodox Marxist economists predicted that the rising organic composition of capital and the tendency for the rate of profit to fall presaged a sequence of ever deepening economic recessions (1973-1975, 1981-1982, 1990-1991, 2000-2003, 2008-2010). Gorz (1986, p. 9) concludes that in late capitalism "the tendency that Marx (within quite different parameters) described as 'the rise in organic composition of capital' was thus borne out in the increasing substitution of constant (fixed) capital for variable (circulating) capital."9 Indeed, the essential characteristic of post-industrial capitalism has been the displacement of human labor power (both intellectual and manual) with automated and digital technology.

However, Gorz also concludes that the failure of Marxian economics to correctly predict rising profits and economic growth along with rising unemployment and underemployment during the 1980s was due to a fundamental theoretical error in Capital. It has often been pointed out, as Gorz (1986, p. 11) notes correctly, that while Marx links the tendency for the rate of profit to fall to the rising organic composition of capital, there is no mathematical (i.e., logical) necessity for profits to fall as the organic composition of cap-

Similarly, Offe (1984, p. 92) argues that "social policy is the state's manner of effecting the lasting transformation of non-wage laborers into wage-laborers."

See also: Mandel (1978); Baran and Sweezy (1966).

See: Marx (1977, pp. 197-456, 671-710). 
ital rises. Rather, the falling rate of profit and the rising organic composition of capital are linked historically in Capital to the success of the class struggle which leaves capitalists with no alternative but to either substitute constant capital for variable capital (factor substitution) or flee to areas of lower labor costs (globalization). ${ }^{10}$

When capitalists were confronted historically with this long-term crisis, as institutionalized in the welfare state, the capitalist enterprises that were capable of doing so resolved the profits squeeze of the 1970s (Glyn, Sutcliffe, 1972) with one or both of two strategies: (a) flight to less developed countries (globalization) and (b) the substitution of technology for human labor power (Clarke, 1991, pp. 9-13). In this respect, the orthodox Marxist analysis of late capitalism correctly forecast a deep, recurring, and protracted crisis of capitalism but, according to Gorz (1986, p. 6), because the socialists' solution to that crisis was anchored in the continuing advance of organized labor they were incapable of "breaking from the logic of capitalism." This is not to say that the conceptual tools for such a break could not be found in Marx, but that articulating these concepts required Marxists to "break with the law of value" (Gorz, 1986, p. 43). ${ }^{11}$ In other words, as Offe (1984, p. 283) notes, such a break implies that assumptions "about the centrality of labour within classical Marxism must also be questioned." 12

This question was posed in Volume 1 of Capital, where Marx (1977, p. 762) equates the rising organic composition of capital "with the fate of the working class." Marx (1977, p. 571) defines the composition of capital as "the ratio of its constant to its variable component." He observes that "with the introduction of machinery the composition of the total capital is altered [...].every advance in the use of machinery entails an increase in the constant component of capital, that part which consists of machinery, raw material, etc., and a decrease in its variable component, the part laid out in labour-power" (Marx, 1977, pp. 577578). The tendency for the ratio of constant capital to grow at the expense of variable capital is called the rising organic composition of capital. ${ }^{13}$

10 Significantly, Marx (1977, pp. 570, 577-578) first introduces the concept of the rising organic composition of capital in the chapter on the working day.

11 The law of value is a claim that the valorization of a commodity is determined by the labor time "socially necessary for the production of a use-value," see: Marx (1977, p. 303).

12 Similarly, Laclau and Mouffe (1985).

13 Marx (1977, p. 762) states that “... as it functions in the process of production, all capital is divided into means of production and living labour-power...I call the former the value-composition of capital, the latter the technical composition of capital. There is a close correlation between the two. To express this [ratio], I call the value-composition of capital...the organic composition of capital. Wherever I refer to the composition of capital, without further qualification, its organic composition is always understood." 
Moreover, Marx argues that:

this law of the progressive growth of the constant part of capital in comparison with the variable part is confirmed at every step [...] the growing extent of the means of production, as compared with the labour-power incorporated into them, is an expression of the growing productivity of labour. The increase of the latter appears, therefore, in the dimunition of the mass of labour in proportion to the mass of means of production moved by it [...].This increasing accumulation and centralization also becomes in its turn a source of new changes in the composition of capital, or in other words of an accelerated dimunition of the variable component, as compared with its constant one. This accelerated relative dimunition of the variable component, which accompanies the accelerated increase of the total capital and moves more rapidly than this increase, takes the inverse form, at the other pole, of an apparently absolute increase in the working population [...], but in fact it is capitalist accumulation itself that constantly produces, and produces indeed in direct relation with its own energy and extent, a relatively redundant working population, i.e., a population which is superfluous to capital's average requirements for its own valorization, and is therefore a surplus population (1977, pp. 773, 781-782).

In Capital, Marx mainly utilizes the rising organic composition of capital to explain the long-term tendency for the rate of profit to fall in capitalism, but he does not explore the long-term tendency for the rising organic composition of capital to continue generating a surplus population. Marx's conceptualization of the surplus population as an industrial reserve army still views this population as a segment of the working class that grows and shrinks with the business cycle to discipline wages. However, in Capital, Marx never entertains the possibility of an indefinite growth of the ratio of the surplus population, or its qualitative transformation into a permanent non-working class, because in Capital, Marx assumes that the proletarian revolution will have socialized the means of production long before such a transformation could occur in reality. ${ }^{14} \mathrm{He}$ also does not envision a full rupture in the law of value, i.e., the ability of technology to independently generate use value and exchange value.

However, Marx often questions this very assumption in the Grundrisse as documented by Gorz, Offe, Habermas, and Negri. For example, Gorz identifies numerous passages in Grundrisse which suggest that a technological revolu-

14 Marx (1977, p. 929) concludes that "The centralization of the means of production and the socialization of labour reach a point at which they become incompatible with their capitalist integument. This integument is burst asunder. The knell of capitalist private property sounds. The expropriators are expropriated." 
tion will completely transform the logic of capitalist development by overturning the law of value, i.e., that the value of a commodity is determined by the socially necessary labor-time required to produce it. This break in the law of value undermines the foundation of economic reasoning in Capital. Specifically, Gorz (1986, pp. 45, 29) finds that "the disappearance of market laws (as Marx showed in the Grundrisse), just like the disappearance of the law of value, is an inevitable consequence of automation." ${ }^{15}$ Gorz, Offe, Negri, and Habermas all agree that Marx's Grundrisse anticipates a rupture in the law of value, but they are equally critical of Marx for thinking that such a rupture would generate:

[...] a process in which the development of the productive forces would result in the replacement of the army of unskilled workers and labourers - and the conditions of military discipline in which they worked - by a class of polytechnic, manually and intellectually skilled workers who would have comprehensive understanding of the entire work process, control complex technical systems and move with ease from one type of work to another (Gorz, 1982, p. 27). ${ }^{16}$

Gorz (1982, p. 28) argues "that exactly the opposite has occurred" from what Marx anticipates, because "automation and computerisation have eliminated most skills and possibilities for (workplace) initiative and are in the process of replacing what remains of the skilled labour force (whether blue or white collar) by a new type of unskilled worker." ${ }^{17}$ Similarly, in Knowledge and Human Interests, it is rarely noted that Habermas (1971, pp. 326-329 fn. 7-13) submerges an extended analysis of Grundrisse in a series of footnotes that anchor his epistemological position and that later provide the basis for his analysis of the crisis tendencies of late capitalist systems in Legitimation Crisis. As with Gorz, Habermas identifies key passages in Grundrisse that anticipate a technological future where

15 Gorz (1986, p. 33) quoting Grundrisse notes that "Marx forecast that 'the transformation of the means of labour into the automatic process' would go together with 'the abolition of direct individual labour and its transformation into social labour'” Similarly, see: Rockmore (1989, Chap. 8) for an analysis of Habermas' critique of Marx's labor theory of value. On Negri, see: Caffentzis (2011, pp. 101-125).

16 Gorz (1967), embraced this same logic earlier in his thinking as did several other "new working class" Marxists. For example, Mallet (1975); Touraine (1971). More recently, see: Bowles, Gordon, and Weisskopf (1990).

17 Gorz (1982, p. 70 fn. 3, 71 fn. 4) notes that Marx was well aware of this trend as documented in Grundrisse where, "after describing with remarkable prescience the separation of the labourer from science and technology, as they acquired the reified form of fixed capital in the means of production [i.e., automation and computerization], Marx went on nevertheless to predict that, thanks to the freeing of time, fully developed individuals would become the subjects and agents of the immediate process of production. The polytechnic and scientific development of the individual through automation is an illusion." 
"knowledge is itself potentially a productive force." ${ }^{18}$ Most importantly, Habermas (1971, pp. 48-49) identifies "an unusual passage" from Grundrisse, which does not recur in the parallel investigations in Capital:

$[\ldots]$ to the degree that large-scale industry develops, the creation of real wealth comes to depend less on labor time and on the amount of labor employed than on the power of the agencies set in motion during labor time, whose 'powerful effectiveness' is itself in turn out of all proportion to the direct labor time spent on their production, but depends rather on the general state of science and on the progress of technology, or the application of this science to production [...] the surplus labor of the mass has ceased to be the condition for the development of general wealth [...] (Marx, 1973b, pp. 704-705). ${ }^{19}$

Since the objective of investing in constant capital is to facilitate increases in productivity and, therefore, in the rate of exploitation, value-generating technology emerges as the postindustrial conclusion to the rising organic composition of capital described by Marx in Capital. However, this conclusion to the logic of industrial capital implies that the law of value (labor) gradually ceases to organize capitalist power relations. As the law of value is ruptured by the rising organic composition of capital, Offe (1984, p. 284) observes that the capitalist labor market correspondingly shrinks "in its potential for determining both relations of social and political power and collective identity." As a power mechanism, the capitalist labor market remains basic to an understanding of capitalist society, but as it contracts "an ever smaller part of the entire social structure is directly determined by it" (Offe, 1984, p. 284).

\section{Decommodification: The New Social Groups}

The labor market can only function as a determinative power-generating system to the extent that it organizes individuals within its matrix of social relations. However, Post-Marxist theorists contend that the automation and digitisation of production (i.e., the rising organic composition of capital) are eroding

18 Similarly, Habermas (1971, p. 36) observes that: "The knowledge generated within the framework of instrumental action takes on external existence as a productive force." For example, Habermas (1971, p. 47) quoting Grundrisse: "The development of fixed capital indicates the extent to which general social knowledge has become an immediate force of production and therefore (!) the conditions of the social life process itself have come under the control of the general intellect." See: Marx (1973b, p. 706) for original citation. 
the labor market's power-generating capacities by its contradictory tendency to produce a growing surplus population (Offe, 1972). The surplus population of a capitalist society consists of those individuals who are non-productive in the technical sense that they no longer contribute to the creation of surplus-value (i.e., profits, rents, and interest). Paradoxically, the labor market's capacity to absorb the individuals who depend on it for wages and salaries is shrinking primarily because of increases in productivity (cf. Bluestone, Harrison, 1982).

For the first time in capitalist societies, Post-Marxists envision a developing employment crisis that is not related to a short-term cyclical downturn or to falling rates of investment. Quite the contrary, investment in growth-generating, productivity-enhancing technologies is resulting in the structural disintegration of capitalist labor markets. The new pattern of postindustrial development has three structural consequences of significant import (Hirsch, 1983). First, reduced market demand for labor-power is creating a long-term tendency toward rising structural unemployment. Second, the same forces are yielding institutionalized patterns of structural underemployment in the form of casual labor markets, part-time work, migratory, and informal labor. Third, there is an increasing tendency for individuals to get locked into peripheral labor markets in an emerging low-wage, no-benefits, part-time service sector (Offe, 1985a, pp. 101-128).

Thus, contrary to the expectations of neo-conservative postindustrialists, Post-Marxists do not envision a tertiary service sector based in a professional and technical middle-class, but instead envision a growing peripheral labor market that is neo-proletarian or even lumpenproletarian. ${ }^{20}$ As a result, Post-Marxists were virtually unanimous in predicting the political displacement of the classical Marxian proletariat by a postindustrial population that is economically and socially marginal to the labor market. Gorz (1996, p. ix) refers to this component of the surplus population as a new "servile class," which is defined structurally more by its status as a largely non-working class that lacks permanent or institutionalized participation in capitalist labor markets. At the same time, the structural contraction of the labor market systematically throws off a-functional social tailings. These labor market tailings consist of the chronically unemployed and unemployable; the underemployed; youth that are socially and culturally anomic; a growing class of pensioners with burgeoning health care demands; and a servile class with growing social welfare requirements.

Finally, Post-Marxist new social movement theory emphasizes that the social actors within these new groups do not rely for their political self-identity on the established left-right ideological spectrum, which defines political positions in relation to distributional issues. These actors do not define their collective

20 For example, contrast Gorz (1982) with Bell (1973). 
identities in terms of class- or labor market-based positions such as lower, middle, working, or capitalist class. Instead, their de-commodification makes it possible for them to redefine political space through a multiplicity of other identities such as gender, age, race, nationality, ethnicity, locality, sexuality, and life-style. In each case, political claims are advanced from social locations uncoupled from class positions and other identities defined by participation in the labor market.

\section{One Future: 'Communism' as the Entitlement State}

Offe (1973) and Gorz (1986) particularly emphasize that the growth of a surplus population places exponentially more pressure on state social policy because the new social groups exist outside the logic of labor commodification; that is, their redistributive demands are not linked to labor market participation but directly to social need. Consequently, Offe (1984, p. 40) suggests that the new social groups are impediments, threats, and ballast to further capitalist development because their members do not contribute to the process of surplus value creation, but they do make chronic demands on the state's redistributive capacities.

For this reason, the logic of postindustrial socialism is necessarily linked to the development of the new non-working classes. Gorz (1986, p. 1) observes that in classical Marxism the concepts of work and the proletariat refer "almost exclusively to activities carried out for a wage." Hence, these concepts are connected logically to the maintenance of the economic structures organized by a labor market, which includes both capitalism and socialism. On the other hand, Gorz (1986, pp. 2-3) argues that the post-industrial New Left is concerned with "liberation" and therefore with the creation of "free time," where "individuals can exercise control over their bodies, their use of themselves, their choice of activity, their goals and productions." Thus, the objective of post-industrial socialism is not workers' control of the means of production and the labor process, but the abolition of work and the liberation of time.

Gorz argues that the abolition of work is already underway and it is a process that is likely to accelerate in the coming future. As noted earlier, Gorz identifies the technological revolution as the engine of this historical development, particularly automation, robotics, and digitisation. In Gorz's (1986, p. 3) grand historical narrative, automation is making it "absolutely impossible to restore full employment by quantitative economic growth." Gorz (1986, p. 31) observes in Paths to Paradise that "in the fully automated factory, the quantity of living labour drops towards zero, and so does purchasing power distributed as wages." Consequently, he concludes it is not an exaggeration to predict unemployment rates of 30 to 50 percent by early $21^{\text {st }}$ century. 
This may sound like a fantastic proposition at a time when the official U.S. unemployment rate is hovering around 4.3 percent. However, Gorz's observation is not based on official unemployment statistics, but on the Marxian proposition that the socially necessary labor time required to produce an ever larger volume of goods and services is rapidly shrinking over time, i.e., the labor-market itself is contracting and thus adult labor market participation is a better measure of "employment" and "unemployment." In fact, in post-industrial societies it is already the case that half or more of the adult population no longer participates in the labor market on a full-time basis, if one combines pensioners, high school and college students, social welfare recipients, the compensated unemployed, the uncounted (unofficial) unemployed, the disabled, the homeless, and part-time employees. A very large proportion of this non-working class is dependent on the social distribution of non-wage and non-salary income and on other forms of indirect subsidies (e.g., government-sponsored health care, free public education, subsidized higher education, etc.).

The only question is whether the abolition of work will take the form of a society based on mass unemployment - itself a socially constructed idea linked to the existence of labor markets - or a society based on free time where everyone shares equally in the benefits of reduced work. Gorz (1982, p. 4) argues that "the manner in which the abolition of work is to be managed and socially implemented constitutes the central political issue of the coming decades." Gorz (1982, p. 4) concludes that a political solution to this problem will require a post-Marxian social policy, because it calls "for new mechanisms of distribution independent of the laws of the market and the 'law of value."'

Furthermore, to avoid the potential social disorder that would follow in the wake of a mass unemployment scenario, Gorz contends that the welfare state will remain a permanent fixture of post-industrial capitalism that is forced to redistribute a minimum income without regard to work or productivity. Even after the Reagan-Thatcher Revolution, and the rise of neo-liberalism, it is still the case that over half of all economic resources in post-industrial societies are distributed on a political basis, rather than by markets, if one combines direct government spending with the resources allocated indirectly by government through statutory mandates (e.g., minimum wage, environmental regulation, monetary policy, etc.). Thus, the second key issue of postindustrial socialism is "the social form which income takes when automation has abolished, along with a permanent obligation to work, the law of value and wage labour itself" (Gorz, 1982, p. 4).

Thus, in contrast to his earliest writings, Gorz vigorously rejects the skilled proletariat as the subject of post-industrial socialism, along with its organizations, such as trade unions and social-democratic parties. Gorz (1982, pp. 4-6) contends that "automation will always be perceived by skilled workers as a di- 
rect attack on their class insofar as it undermines workers' class power over production." Consequently, the major concern of fully employed skilled workers is to resist automation by protecting job security and skill monopolies. This means that "the main strategic goal of this stratum, which has always been hegemonic within the organised labour movement, will remain the appropriation of work, of the work tools and of power over production."

A second reason that skilled workers will oppose automation is that their collective identity is defined by the application of skills at the point of production, i.e., by work. Hence, for organized labor, "the abolition of work is neither acceptable nor desirable" (Gorz, 1982, p. 6), because it undermines the social conditions which define them as a privileged social group within the labor market. Therefore, Gorz (1982, pp. 6-7) is certain that a defensive strategy against automation - one that is technologically determined to fail - will remain the major concern of traditional trade unionism, or in a more radical turn towards syndicalism, the same objective will be asserted in the form of workers' control and autogestion movements.

Gorz decisively abandoned the new working class thesis developed in his Strategy for Labor (1967) mainly because he reversed his assessment of computer technology and robotics. Gorz (1982, p. 28) quickly concluded that he was wrong to ever believe that "the refinement and automation of production technology would lead to the elimination of unskilled work, leaving only a mass of relatively highly skilled technical workers, capable by their comprehensive understanding of the technico-economic processes of taking production under their own control." In contrast to neo-conservative (Bell, 1973) and neo-liberal (Reich, 1991) post-industrialists, Gorz (1982, p. 28) is persuaded that "automation and computerisation have eliminated most skills and possibilities for initiative and are in the process of replacing what remains of the skilled labour force (whether blue or white collar) by a new type of unskilled worker." Consequently, Gorz dismisses the autogestion and workers' control movement as a basis for postindustrial socialism. In fact, Gorz (1982, p. 8) now considers techno-syndicalism a reactionary attempt to "reestablish the old crafts [...] so that autonomous groups of workers may control both production and its products and find personal fulfillment in their work."

Gorz (1982, pp. 9, 31) became convinced that automated and cybernetic work processes are inherently heteronomous and therefore alienation is an inevitable consequence of the socialisation of the labor process. The socialisation of labor means that increasingly "the nature, modalities and objectives of work are, to a large extent, determined by necessities over which individuals or groups have relatively little control" (Gorz, 1982, p. 9). The externality and exteriority of the collective worker (i.e., the historical subject) in relation to particular (i.e., 
individual) workers is now "inherent in the material structure of the productive apparatus and in the nature of the physical processes it governs" (Gorz, 1982, p. 31). Hence, the liberation of time must occur outside the workplace; that is, in the abolition of work:

[...] for workers, it is no longer a question of freeing themselves within work, putting themselves in control of work, seizing power with the framework of their work. The point now is to free oneself from work by rejecting its nature, content, necessity and modalities (Gorz, 1982, p. 67).

Gorz pursues the institutional implications of this thesis for a post-industrial socialism across two lines of analysis. First, Gorz (1982, p. 12 fn. 8) points out that in traditional Marxism as outlined in Critique of the Gotha Program:

[...] socialism is a transitional stage towards communism. During this transition, the development and socialisation of the productive forces is to be completed; wage labour to be retained and even extended. The abolition of wage labour (at least as the dominant form of work) and market relations is, according to the schema, to be realised with the advent of communism. ${ }^{21}$

Gorz maintains that "in advanced industrial societies, socialism is already historically obsolete," because "political tasks have now gone beyond the question of socialism, and should turn upon the question of communism as it was originally defined" in Critique of the Gotha Program and The German Ideology. Gorz (1982, p. 12 fn. 8) observes that the technological revolution allows "the production of a growing volume of commodities with diminishing quantities of labour and capital" and, consequently, the "aims and methods of economic management clearly cannot remain those of capitalism, any more than social relations can remain based on the sale of labour power, that is, on waged work." However, Gorz also concludes that:

[...] neither can this management be socialist, since the principle 'to each according to his labour' has become obsolete and the socialisation of the productive process (which, according to Marx, was to be completed by socialism) has already been accomplished. Automation, therefore, takes us beyond capitalism and socialism (1986, p. 32).

${ }^{21}$ See: Marx (1973b, pp. 8-10 passim), where socialism is defined as "the first phase of communist society." Marx observes that "as it [communism] emerges from capitalist society," the same principle of distribution "prevails as in the exchange of commodity-equivalents, so much labour in one form is exchanged for an equal amount of labour in another form," i.e., from each according to his ability, to each according to his labor. 
Gorz (1982, p. 123) muses that the term "post-industrial socialism" is actually inappropriate for describing post-Marxist political movements. He notes that the proper

Marxist terminology would have us refer straightforwardly to 'communism', meaning that stage in which the 'fullest development of the productive forces' has been realised and where the principal task is no longer to maximise production or assure full employment, but to achieve a different organisation of the economy so that a full day's work is no longer a precondition for the right to a full income [...]. We have almost reached that stage. ${ }^{22}$

Gorz $(1989$, p. 209) has little to say about political strategy, but he identifies the central principle of postindustrial socialism with establishing a new definition of "full-time" employment or a "new organization of time." Gorz suggests that the central objective of post-industrial socialism should not be the promotion of a full-employment economy as defined by the capitalist labor market, but a policy of redistributing the economically necessary quantity of work across society. He argues that state policy should gradually phase in a reduction of what constitutes full-time employment as the socially necessary labor time for producing an increasing quantity of goods and services continues to decrease in the coming decades. In fact, the state has enforced such a policy in the past by instituting the 10-hour day, the 8-hour day, and the 40 -hour week without any reduction in annual compensation. Thus, such a proposal is far from utopian.

In this conception of post-industrial socialism, the state's main policy initiative would be to reduce the statutory definition of full-time employment from 1,600 hours per year to an average of 1,400 hours, to 1,200 hours and, finally, to 1,000 hours over a span of 15 to 20 years. These 1,000 hours of work annually would be considered the normal definition of full-time employment. It will entitle each individual to a normal wage, which corresponds to a particular level of skills and qualifications, just as the current 1,600-hour year is considered the full-time norm and gives one the right to draw a fulltime wage or salary. This strategy is consistent with Marx's own emphasis on the struggle for the working day, which is the single longest chapter in Capital. The working day is a legal - not merely an economic - concept (Commons, 1924).

22 See also: Levine (1993). Gorz's equation of liberation with the abolition of work under communism also draws heavily on Marx's distinction between "the realm of necessity and the realm of freedom" in Capital, vol. 3, see: Tucker (1978, pp. 439-441). 
The key to adopting this principle would be to simultaneously establish an equal right to employment and free time for all. In a post-industrial society, it is only by working less that everyone can exercise the right to work. Gorz emphasizes that an essential aspect of post-industrial socialism will be "an obligation to work in exchange for a guaranteed full income" (1989, p. 211), since it is the obligation to work that provides the basis for the corresponding entitlement right. By requiring individuals to produce the income that is guaranteed to them, society simultaneously obligates itself to guarantee each individual the opportunity to work.

Gorz predicts that the obligation to work will be necessary in post-industrial socialism, because as the length of annual working time decreases, work will tend to become more and more intermittent. A thousand hours annually of labor may be completed in two days a week, ten days a month, two fortnights every three months, 40 hours every other week, one month out of two, or six months a year. As Gorz notes, one could articulate endless permutations on this type of system, make provision for bonuses or penalties, and for fiscal incentives or disincentives to work for either long or short periods of time.

Despite its libertarian thrust, Gorz (1986, p. 78) concedes that postindustrial socialism, or more appropriately communism, "will still entail planning, and planning requires a state." However, Gorz suggests that communist governance will be little more than a social security accounting system which records labor time and processes checks, while insuring that the hours of labor and the guaranteed income received by that person are in balance over a person's lifetime. Thus, Gorzian communism results in a stateless society in the Marxian sense that "the government of persons is replaced by the administration of things" (Engels, 1939, p. 307). For Gorz, as for many Post-Marxists, the welfare state is the embryo of a compensatory political mechanism designed to de-couple income distribution from the labor market and the law of value. Yet, in fact, the existing welfare state utilizes dependency on redistribution as a mechanism for regulating individual and social behavior by imposing behavioral qualifications on supervised access to redistribution. Thus, Gorz (1982, p. 42) acknowledges that the actually existing welfare state is an "apparatus of domination and administration, whose unrestricted power runs down towards a dislocated society which it endeavors to restructure according to the requirements of capital." Gorz concludes that any continuation down this path of political development "can only lead to the state taking greater charge of individual lives [...]. It replaces or complements, as the case may be, exploitation with welfare, while perpetuating the dependence, impotence and subordination of individuals to centralised authority" (1986, p. 4). Gorz (1986, p. 18) agrees that it is hard to see how a servile "non- 
class" could seize power and redefine entitlements as a new form of property rights, but like so many post-Marxists, he dismisses the issue of historical agency as "beside the point." ${ }^{23}$

\section{Another Future: 'Communism' as the Stateless Entitlement}

Claus Offe has been more attuned to the agency problems that labor market disintegration poses for a theory of the socialist state. In the 1970s, Offe predicted that the state's dependency on capital accumulation would at some point require the welfare state to shed its sociological ballast (i.e., the surplus population) to maintain capital accumulation at more optimal levels (cf. Olson, 1984). In contrast to Gorz, Hinrichs, Offe, and Wiesenthal (1984-1985, p. 51) concluded that the adoption of such policies would entail "a downward redefinition of the welfare state's legal entitlements and the claims granted by it, most of all the claims of those groups that are least well organized and hence least likely to engage in collective conflict." The Reagan-Thatcher-Kohl initiatives of the 1980s are consistent with this prediction as are the initiatives of the International Monetary Fund on a global scale. The rise of global capitalism from the 1990s onward has only accelerated these tendencies on a larger scale.

Yet, the contradiction of these initiatives in a capitalist society is that dependent distributive groups are set adrift even as the absorption potential of the capitalist labor market continues to shrinks. Thus, the labor market's power to economically determine relations of political power, and to shape collective social identities, dissipates. However, the declining absorption capacities of capitalist labor markets thus remove or exclude an increasing number of potential workers from direct and full-time contact with the central power mechanism of capitalist society (Offe, 1985a, p. 3). Consequently, capitalists lose their direct hold on the population, because the dependency principle - whether exercised by the state or the labor market - is unable to subordinate larger and larger segments of the population. The social drift of postindustrial capitalism is what allows the new social groups to become systemic agents of a potential counter-movement for a postindustrial socialism based on claims to entitlements without work (Offe, 1985b) ${ }^{24}$

23 Little (1996, p. 99) observes that "at no stage did Gorz state that the neo-proletariat is becoming a 'single revolutionary subject'. He defines it as a group that no longer relates to the work ethic and is therefore opposed to the logic of capitalism. This does not mean that Gorz believes that the neo-proletariat will achieve revolutionary class consciousness; in the present situation, this development is most unlikely."

24 Offe $(1984$, p. 285$)$ argues that the revolutionary potential of the labor movement "has been exhausted to the extent that it ignores the fact that the wage-labour-capital relationship is not 
For example, Offe points out that by the 1990s, there were more university students in the European Union than craft apprentices in the skilled trades. There are more unemployed people than farmers and more pensioners than blue collar workers. Significantly, the more numerous social groups are defined more by their legal ownership of entitlement rights than by their place in the social relations of production (cf. Reich, 1964). In fact, these groups are outside the production system, in a strict sense, and thus establish their group identity and claims to income through public policy. Hence, Offe (1996, p. ix) describes these groups as "policy-takers," because the place they occupy within the social division of labor and consumption is policy-determined, rather than economically determined.

Offe suggests that the contradiction of these groups' social location is the powerlessness of state power. The state's dependency on capital accumulation renders it powerless as a mechanism of social transformation so that any statist solution, whether a traditional social democratic or a communist one is clearly unrealistic in Offe's view (cf. Przeworski, 1980, 1985). Furthermore, as identities move beyond the workplace in post-industrial capitalism, Offe insists that the concept of politics must be extended beyond the sphere of the state and its existing institutional channels. Thus, the paradox of postindustrial socialism is that "socialism in industrially advanced societies cannot be built without state power and it cannot be built on state power" (Offe, 1984, p. 246). A socialist state can maintain its directive capacity as a political organization "only to the extent that it gives itself up as a state - that is to say as a separate organization of the ultimate power of collective decision-making - ultimately by negating its identity as an 'apparatus' and eliminating the categorical distinction of 'state' and 'civil society"' (Offe, 1984, p. 246).

Offe is acutely aware of the difficulties that the new social groups pose for a theory of the socialist state. The new social groups define conflicts in terms of entitlement values and social rights that are non-negotiable principles, but these rights can only be asserted politically. Consequently, the contradiction of the capitalist welfare state is that it cannot maintain capital accumulation without shedding a non-productive surplus population from its ledgers, but it cannot maintain its democratic legitimacy without distributing entitlement rights to the new social groups. Yet, despite their inherently political determination, the new social groups are distinctively libertarian and anti-statist in their politics.

the key determinant of social existence and that the survival of capitalism has become increasingly contingent upon non-capitalist forms of power and conflict. Any labour movement that ignores this and avoids trying to make links with conflicts generated by consumers, clients, citizens, or inhabitants of an ecosystem becomes solipsistic. In my view, the crucial problem for the labour movement is how to become more than a labour movement." 
Offe (1984, p. 243) posed the paradox of postindustrial socialism as early as 1978 when he began asking "whether the structural conditions of advanced capitalism are, in fact, conducive to non-statist forms of socialist transformation." From a systemic perspective, the possibility of postindustrial socialism hinges on whether the developmental logic of the capitalist system facilitates, or at least make possible, "the implementation of the classical idea that the occupation of state power has to be followed by its structural transformation and democratization." Offe (1996, p. 25) is now convinced that capitalist states are resolving the contradiction between accumulation and legitimation by institutionalizing a new configuration of societal steering mechanisms.

By the late 1970s, Offe (1984, p. 249) hypothesized that the capitalist state would undergo structural changes of a corporatist nature under the impact of future economic crises and that these structural changes "could favour and facilitate a non-statist socialist strategy." Offe defines corporatist-style changes in the state with "a dissolution of the institutional separateness, or relative autonomy of the state, the withering away of the capitalist state as a coherent and strictly circumscribed apparatus of power." This process of withering away is one in which "policy-making powers are 'contracted out' to consortia of group representatives who engage in a semi-private type of bargaining, the results of which are then ratified as state policies or state planning."

From a historical perspective, Offe suggests that the contradictions of the welfare state are being resolved through a compromise solution which maintains entitlement spending levels, while reducing the administrative and rationality demands on the state. This solution is being implemented through the devolution of numerous state functions to voluntary associations and non-profit organizations. The state is essentially dissolving itself back into civil society; a development that presages the withering away of the state into a democratically self-administered society.

As with Gorz, Offe argues that a state guaranteed annual income must be the core social policy of post-industrial socialism. In contrast to Gorz, however, Offe proposes "a sociocultural standard of need" as the basis for defining guaranteed income levels, rather than socially necessary labor time. As technological advances erode the operative sphere of the law of value, it is the production process itself that ruptures the link between labor and value. Therefore, the process of postindustrial development not only establishes the political conditions for postindustrial socialism (i.e., the surplus population), it erodes the institutional foundation that supports a normative commitment to the work ethic. Thus, Offe (1996, p. 201) concludes that it should become increasingly "possible to make the right to an income independent of the fact and extent of an individual's income-earning activity." 
The administration of this system of stateless entitlements is linked closely to Offe's conception of contemporary political development as a "withering away of the state." Offe contends that a centuries-long process of political development is being reversed insofar as the state is defined by the territorial centralization of political authority, the establishment of a monopoly on the legitimate use of force, and the subordination of all competing forms of secular and ecclesiastical power to the state. Offe (1996, p. 64) argues that for the first time in centuries public duties are being delegated to "para-constitutional authorities and procedures, in which the state participates more -if at all - in the function of a coordinator or moderator than as a sovereign authority giving orders and exerting power."

What distinguishes this stateless entitlement from the entitlement state is that strong intermediate organizations stand between the state and the individual. In place of a disorganized mass that is dependent on state allocation policies, Offe sees a trend toward the strengthening of intermediate organizations that are legally private, but which are capturing sovereign functions from the state. As the state becomes overloaded with demands on its administrative capacities, it continues to delegate and disperse regulatory and distributive powers to quasi-public corporations, trade associations, professional organizations, social service corporations, labor unions, chambers of commerce, scientific associations, and other private non-profit organizations. These collective actors are being delegated quasi-sovereign functions (or usurp these functions) and thereby relieve the state of a number of responsibilities, especially those functions that involve the public distribution of goods and services. Different scholars have described this tendency as a form of postindustrial neo-corporatism (Schmitter, 1985), post-capitalist society (Drucker, 1993), the re-feudalization of political authority (Poggi, 1990), and the privatization of government (Hirst, 1989, pp. 1-46).

The state merely provides an arena for distributive bargaining among these organizations and an administrative office for collecting and allocating the social product. In this sense, the state is being gradually deprived of its functions by making them societal. The state will provide coordination to society through para-governmental procedures, but will otherwise engage in an ordered retreat by devolving institutional structures, procedures, participative conditions and competencies into civil society and its associations. By acting as a steering and rule-making organization, the state can unburden itself of political and administrative demands, but also provide a mechanism that avoids "the danger that these areas would regress into the anarchy of market processes or dynamics determined by particular interests" (Offe, 1996, p. 69). 


\section{A Third Future: Statist Disentitlement}

Gorz and Offe both identify developmental tendencies that are making postindustrial socialism a historical possibility and that assign this political mission to the surplus population. At the same time, Gorz is convinced that the dominant trend in contemporary economic development is toward the option based on mass unemployment. Gorz (1982, pp. 3, 7) envisions a postindustrial social structure that consists of "a growing mass of the permanently unemployed on one hand, an aristocracy of tenured workers on the other, and, between them, a proletariat of temporary workers carrying out the least skilled and most unpleasant types of work." However, Gorz observes that the latter jobs will be largely eliminated by automation in the near future; hence, promoting the historical tendency toward a mass unemployment society. This means that "the abolition of work can have no other social subject than this non-class."

However, this retains historical agency at the center of the transition problem. Gorz (1982, pp. 10-11, 36) acknowledges the dilemma that the so-called non-class is not really a social subject since "it has no transcendent unity or mission, and hence no overall conception of history and society." The non-class is really a disorganized mass of dissociated individuals and this social base makes postindustrial socialism libertarian to the core. Gorz concedes that the libertarian thrust of the new social movements is at once their strength and weakness, with the obvious weakness being an "obvious incapacity to seize power." Thus, Gorz can offer no more practical advice about political organization than a concept of historical agency anchored by the specifically existential demand for individual autonomy and free time. ${ }^{25}$ Gorz suggests that the desire for autonomous free space is an existential need with its own irreducible reality.

The existential character of Gorz's (1982, p. 11) politics means that the initial phase of a postindustrial socialist revolution must concentrate on a politics aimed at opening up new spheres of individual autonomy in which individuals can "invent and implement new relationships and forms of autonomy," which is a way of saying that because everyone is unemployed they can spend more time at the Louvre, the pub, or a mass demonstration (Hirsch, 1981; Poster, 1997). Yet, Gorz also recognizes that a major problem with this libertarian emphasis is that autonomous spaces captured from the existing social order will be systematically marginalised, subordinated, and ghettoised unless there is a full transformation and reconstruction of society, its institutions and legal systems. The prob-

25 Lévy (1979, p. 68), who describes the new philosophy as a call for "a provisional politics, a smallscale program, which some of us think can only be precarious, uncertain, and circumstantial - in a word, a matter of feeling." 
lem is that Gorz can't get there from here because he understands that large-scale social transformations are not effected by individuals. A social transformation of this magnitude implies an overall vision of what society is to become - and even pluralism as a multiplication of decision-making centers, an increase in individual liberty, and further limitation of the state's role amounts to an overall vision (Gorz, 1982, pp. 12, 78). The dilemma is what organization or social group will carry that vision? ${ }^{26}$

For Offe, it is the fact of the new identity movements that raises doubts about the prospects for postindustrial socialism. Offe concludes that it is "equally questionable for normative and theoretical reasons whether the trends of decomposition and dispersion of the state's sovereignty, authority, and rationality" (1996, p. 67) will result in a new balance of self-regulating, but coordinated civil associations. In fact, the state's weakening in comparison to global markets and strong civil associations increases the risk of societal instability on a national and international scale. The new identities have also set in motion anarchic and anomic dynamics that are destabilizing and reversing modernity and modernization itself. The cleavages opened by the dynamics of the new identity movements are not negotiable within a distributive framework precisely because these social identities are not defined by distributive positions within the labor market or by places within the social relations of production. In this scenario, the Kosovo conflict, the ethnic war in Rwanda, the tribal disintegration of Somalia, the quest for a caliphate, and ethnic conflict in the republics of the former Soviet Union open windows onto the realities of a Post-Modern politics stripped of its neo-romantic literary veneer.

In post-industrial societies, such as the United States, it is the National Socialist Movement, the para-military militia movements, abortion clinic bombers, and Christian fundamentalists, who emerge as the real agents of a post-modern politics that has slipped beyond the grasp of a weakening state challenged by strong civil associations. Offe (1996, pp. 20,67) notes that even in their less extreme manifestations, "the new social movements are not entirely immune from the temptation to revert to unmistakably premodern ideals and to base their critique on particularistic, communitarian, libertarian, anarchistic, ecologicalbiological, or similar fundamentalisms," which define a politics of exclusivity and conflict, rather than democratic pluralism. Offe views this possibility as the more realistic alternative for a post-modern, rather than a Post-Marxist future.

Finally, Habermas has always been ambivalent about the transformative potential of the new social groups, precisely because their marginal attachment to the labor market excludes them from participating in the central power-generat-

26 The best critical analysis of this question is Frankel (1987). 
ing mechanism of a capitalist society. Their displacement from the labor market excludes the neo-proletariat and the servile class from access to its social power in the sense that they do not have anything of economic value (i.e., labor power) to bargain with or to exchange for concessions. ${ }^{27}$ As underemployed, unemployed, or unproductive labor, the neo-proletariat and the servile class are a surplus population that can be marginalized without any significant cost to the capitalist economy, particularly in a global economic system with highly mobile capital.

The theoretical key, as Habermas observes, is that the pauperization of these groups no longer coincides with economic exploitation in the technical Marxian sense, because the system no longer depends on their labor for the creation of surplus-value. Hence, these groups cannot exert any structural leverage by collectively withdrawing their labor from the marketplace and, for the same reason, capital incurs no direct costs from their repression due to lost productivity. Consequently, Habermas (1970, p. 110) concludes that unless these groups "are connected with protest potential from other sectors of society no conflicts arising from such underprivilege can really overturn the system - they can only provoke sharp reactions incompatible with formal democracy" (cf. Offe, 1985b, esp. p. $855 \mathrm{ff}$.). There is good reason to believe that the postindustrial neo-proletariat and servile class is more likely to be an underclass that is easily suppressed, neglected, and contained through coercion and violence. Without significant counter-measures, there is no reason to believe that postindustrial societies will not continue to disintegrate, to become more segmented between a privileged core and a dependent periphery, and consequently to sink deeper into inequality and violence (Gorz, 1986, p. 242).

\section{Conclusion}

A genuinely post-Marxist school of political theory emerged during a brief window from the late 1970s to the late 1980s (at least as those works were translated into English), and even though it was quickly brushed aside by the rise of "globalization studies" in the 1990s (Barrow, Keck, 2017), Post-Marxism established an innovative and prescient analysis of post-industrial and global capitalism that in retrospect now appears more relevant to contemporary political developments than it did at its first appearance. Post-Marxist theorists find an analysis of postindustrial and global capitalism in the Grundrisse that stretches

27 Gorz (1982, p. 67) indicates that these are non-laboring groups "whose social activity yields no power," while such a condition objectively strips it of "the means to take power, nor does it feel called upon to do so." 
Marxian categories - particularly the law of value - to the limits of their applicability; and it does so not because of their inadequacy, but because the developmental logic identified by Marx in Grundrisse is completed in postindustrial capitalism. Thus, Post-Marxists argue that the categories of Capital alone are no longer sufficient for understanding contemporary capitalism; not because Marx was wrong, but precisely because he was correct in his analysis. What makes Post-Marxist theory Post-Marxist is not merely the claim that Marxian concepts need to be supplemented or replaced by new analytic categories, but the contention that Marx so correctly predicted the long-term trends of capitalist development in Grundrisse that a rupture in Capital's law of value now provides the conceptual basis for understanding a disorganized postindustrial and global capitalism. This conceptual shift has enabled Post-Marxists to construct a theoretically powerful analysis of postindustrial capitalism, the new movements, and socialist policy that was remarkably prescient, although none of the Post-Marxists has successfully solved the problem of a contemporary historical subject and political agency. For this reason, Post-Marxist analyses always have the potential to culminate in a dystopian vision of the future, but they raise theoretical, strategic, and policy issues from within Marxism that again warrant serious consideration by the political and academic left.

[...] in a word, oppressor and oppressed, stood in constant opposition to one another, carried on an uninterrupted, now hidden, now open fight, a fight that each time ended, either in a revolutionary re-constitution of society at large, or in the common ruin of the contending classes (Marx, Engels, 1971 [1848], p. 17).

\section{References}

Anderson, P. (1976). Considerations on Western Marxism. London: New Left Books. Aronowitz, S. (1981). The Crisis of Historical Materialism: Class, Politics, and Culture in Western Marxist Theory. New York: Praeger.

Aronson, R. (1995). After Marxism. New York: The Guilford Press.

Baran, P.A., Sweezy, P.M. (1966). Monopoly Capital: An Essay on the American Economic and Social Order. New York: Monthly Review Press.

Barrow, C.W. (1993). Critical Theories of the State: Marxist, Neo-Marxist, Post-Marxist. Madison: University of Wisconsin Press.

Barrow, C.W., Keck, M. (2017). "Symposium/State - Globalization Theory and State Theory: The False Antinomy." Studies in Political Economy, 98 (2), pp. 1-20.

Baynes, K. (2016). Habermas, London-New York: Routledge.

Bell, D. (1973). The Coming of Post-Industrial Society, New York: Basic Books. 
Bluestone, B., Harrison, B. (1982). The Deindustrialization of America. New York: Basic Books.

Boggs, C. (1986). Social Movements and Political Power: Emerging Forms of Radicalism in the West. Philadelphia: Temple University Press.

Borchert, J., Lessenich, S. (2016). Claus Offe and the Critical Theory of the Capitalist State. New York: Routledge.

Bowles, S., Gintis, H. (1982). “The Crisis of Liberal Democratic Capitalism: The Case of the United States." Politics and Society, 11 (1), pp. 51-93.

Bowles, S., Gordon, D.M., Weisskopf, T.E. (1990). After the Wasteland: A Democratic Economics for the Year 2000. Armonk, NY: M.E. Sharpe, Inc.

Caffentzis, G.C. (2011). “Immeasurable Value? An Essay on Marx’s Legacy.” In: P. Lamarche, M. Rosenkrantz, D. Sherman (eds.). Reading Negri: Marxism in the Age of Empire. Chicago: Open Court.

Callinicos, A. (2005). “Antonio Negri and the Temptation of Ontology.” In: T.S. Murphy, A. Mustapha (eds.). The Philosophy of Antonio Negri: Resistance in Theory, vol. 2. London: Pluto Press.

Clarke, S. (ed.) (1991). The State Debate. New York: St. Martin's Press.

Commons, J.R. (1924). Legal Foundations of Capitalism. New York: Macmillan.

Drucker, P.F. (1993). Post-Capitalist Society. New York: HarperCollins Publishers.

Engels, F. (1939). Anti-Duhring: Herr Eugen Duhring's Revolution in Science. New York: International Publishers.

Frankel, B. (1987). The Post-Industrial Utopians. Madison: University of Wisconsin Press.

Giddens, A. (1983). A Contemporary Critique of Historical Materialism, Berkeley-Los Angeles: University of California Press.

Glyn, A., Sutcliffe, B. (1972). Capitalism in Crisis. New York: Pantheon Books.

Gorz, A. (1967). Strategy for Labor. Boston: Beacon Press.

Gorz, A. (1982). Farewell to the Working Class: An Essay on Postindustrial Socialism. Boston: South End Press.

Gorz, A. (1986). Paths to Paradise: Essays on the Liberation from Work. Boston: South End Press.

Gorz, A. (1989). Critique of Economic Reason. London: Verso.

Habermas, J. (1970). Toward a Rational Society. Boston: Beacon Press.

Habermas, J. (1971). Knowledge and Human Interests. Boston: Beacon Press.

Harrison, O. (2014). Revolutionary Subjectivity in Post-Marxist Thought: Laclau, Negri, Badiou. Burlington, VT: Ashgate Publishing Company.

Harvey, D. (1982). The Limits to Capital. Oxford: Basil Blackwell.

Hinrichs, K., Offe, C., Wiesenthal, H. (1984-1985). “The Crisis of the Welfare State and Alternative Modes of Work Redistribution.” Thesis Eleven, 10-11, pp. 37-55.

Hirsch, A. (1981). The French New Left: An Intellectual History from Sartre to Gorz. Boston: South End Press. 
Hirsch, J. (1983). “The Fordist Security State and New Social Movements." Kapitalistate, $10-11$, pp. $75-87$.

Hirst, P.Q. (ed.) (1989). The Pluralist Theory of the State. London: Routledge.

Kriesi, H. (1995). New Social Movements in Western Europe: A Comparative Analysis. Minneapolis: University of Minnesota Press.

Laclau, E., Mouffe, C. (1985). Hegemony and Socialist Strategy. London: Verso.

Levine, A. (1993). Rousseau, Marx, and Communism. Cambridge: Cambridge University Press.

Lévy, H.-B. (1979). Barbarism with a Human Face. New York: Harper and Row.

Little, A. (1996). The Political Thought of André Gorz. New York: Routledge.

Lodziak, C., Tatman, J. (1997). André Gorz: A Critical Introduction. London: Pluto Press.

Marcuse, H. (1964). One-Dimensional Man. Boston: Beacon Press.

Mallet, S. (1975). Essays on the New Working Class. St. Louis: Telos Press.

Mandel, E. (1978). Late Capitalism. London: Verso.

Marx, K. (1971). The Grundrisse: Foundations of the Critique of Political Economy, ed. and transl. by D. McLellan. New York: Harper and Row Publishers.

Marx, K. (1973a). Critique of the Gotha Program. New York: International Publishers.

Marx, K. (1973b). Grundrisse: Foundations of the Critique of Political Economy, transl. with a Foreward by M. Nicolaus. New York: Random House.

Marx, K. (1977). Capital: A Critique of Political Economy, vol. 1. New York: Vintage Books.

Marx, K., Engels, F. (1971 [1848]). The Communist Manifesto. New York: Pathfinder Press Inc.

Negri, A. (1989). The Politics of Subversion: A Manifesto for the Twenty-First Century, transl. by J. Newell. Cambridge, MA: Basil Blackwell.

Negri, A. (1991). Marx Beyond Marx: Lessons on the "Grundrisse", transl. by H. Cleaver, M. Ryan, M. Viano, ed. by J. Fleming. Brooklyn, NY: Autonomedia.

Negri, A. (1999). Insurgencies: Constituent Power and the Modern State, transl. by M. Boscagli. Minneapolis: University of Minnesota Press.

Nicolaus, M. (1968). “The Unknown Marx”. New Left Review, 41 (March/April), pp. 41-61.

Offe, C. (1972). "Advanced Capitalism and the Welfare State." Politics and Society, 2, pp. $479-488$.

Offe, C. (1973). “The Abolition of Market Control and the Problem of Legitimacy (II)." Kapitalistate, 2, pp. 73-75.

Offe, C. (1984). Contradictions of the Welfare State. Cambridge, MA: MIT Press.

Offe, C. (1985a). Disorganized Capitalism. Cambridge, MA: MIT Press.

Offe, C. (1985b). "New Social Movements: Challenging the Boundaries of Institutional Politics." Social Research, 52 (4), pp. 817-868.

Offe, C. (1987). "Challenging the Boundaries of Institutional Politics: Social Movements Since the 1960s." In: C.S. Maier (ed.). Changing Boundaries of the Political. Cambridge: Cambridge University Press. 
Offe, C. (1996). Modernity and the State. Cambridge, MA: MIT Press.

Olson, M. (1984). The Rise and Decline of Nations. New Haven: Yale University Press.

Pierson, C. (1995). Socialism after Communism. University Park, PA: Pennsylvania State University Press.

Poggi, G. (1990). The State: Its Nature, Development, and Prospects. Stanford: Stanford University Press.

Polanyi, K. (1957). The Great Transformation. Boston: Beacon Press.

Poster, M. (1975). Existential Marxism in Postwar France: From Sartre to Althusser. Princeton: Princeton University Press.

Przeworski, A. (1980). "Material Interest, Class Compromise, and the Transition to Socialism." Politics and Society 10 (2), pp. 125-153.

Przeworski, A. (1985). Capitalism and Social Democracy. Cambridge: Cambridge University Press.

Reich, C. (1964). “The New Property”. Yale Law Journal, 73 (5), pp. 733-787.

Reich, R.B. (1991). The Work of Nations. New York: Vintage Books.

Reichelt, H. (2000). “Jürgen Harbermas' Reconstruction of Historical Materialism.” In: W. Bonefeld, K. Psychopedis (eds.). The Politics of Change: Globalization, Ideology and Critique. New York: Palgrave Publishers Ltd.

Rockmore, T. (1989). Habermas on Historical Materialism. Bloomington-Indianapolis: Indiana University Press.

Schmitter, P.C. (ed.) (1985). Private Interest Government: Beyond Market and State. Beverly Hills: Sage Publications, Inc.

Sim, S. (ed.) (1998). Post-Marxism: A Reader. Edinburg: Edinburg University Press.

Sim, S. (2001). Post-Marxism: An Intellectual History. London-New York: Routledge. Touraine, A. (1971). The Post-Industrial Society. New York: Random House.

Touraine, A. (1987). Return of the Actor: Social Theory in Postindustrial Society. Minneapolis: University of Minnesota Press.

Tucker, R.C. (ed.) (1978). The Marx-Engels Reader, $2^{\text {nd }}$ ed. New York: W.W. Norton and Co. Inc.

Weeks, K. (2005). “The Refusal of Work as Demand and Perspective.” In: T.S. Murphy, A. Mustapha (eds.). The Philosophy of Antonio Negri: Resistance in Practice, vol. 1. London: Pluto Press. 